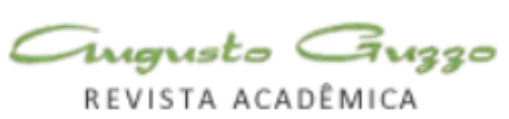

\title{
A hegemonia do feminino em Almodóvar: a presença da maternidade
}

\author{
Bruna Apostólico
}

\section{Resumo}

A pesquisa objetiva abordar os aspectos relacionados à maternidade - o vínculo criado na relação mãe x filho, o cotidiano e o feminino em três obras de Pedro Almodóvar: De Salto Alto (1991), Tudo Sobre Minha Mãe (1999) e Volver (2006). Será observada a transformação social que o diretor promove em seus filmes, rompendo com as estruturas tradicionais, e colocando a mulher como o ser mais importante da sociedade. Ele considera desde as relações afetivas femininas até as profissionais, alcançando assim seus próprios objetivos e as desvinculando da dependência masculina.

Palavras-chave: Almodóvar, cinema, feminino, maternidade.

\begin{abstract}
The research is about the issues related to motherhood - the bond created in the mother $x$ son relationship, the everyday and the feminine in three works of Pedro Almodovar: High Heels (1991), All About My Mother (1999) and Volver (2006). Social transformation will be observed that the filmmaker promotes bis films, breaking with the traditional patterns, and putting the woman as being more important to society will be observed. He believes since the female affective relations to the professionals, thus achieving their own goals and unbinding of male dependence.
\end{abstract}

Keywords: Almodóvar, cinema, female, maternity.

\section{Introdução}

Desde os primórdios, o homem sempre mostrou um interesse na reprodução do movimento. Podemos citar as pinturas rupestres que tinham como objetivo retratar Augusto Guzzo Revista Acadêmica, 2014, N 13 as imagens vistas pelos indivíduos e expressar por meio desses desenhos sua vontade de compartilhar as informações e eternizar-se, deixando suas marcas indeléveis nas paredes. Durante esta evolução surgiram vários 
aparelhos e diversas maneiras de reproduzir o movimento, como a fotografia.

Thomas Edison criou o cinetoscópio em 1890, no qual a imagem só podia ser vista individualmente, e com o aperfeiçoamento desse aparelho os irmãos Lumière desenvolveram em 1895 o cinematógrafo, uma espécie de filmadora que registrava o movimento e permitia a apresentação para o público. As filmagens eram feitas utilizando situações corriqueiras com um foco nos movimentos, por exemplo, os trens em seus trilhos, as pessoas caminhando, crianças correndo/alimentando-se, dançarinas etc, ou seja, não havia uma preocupação com a narrativa. Esse enfoque surge na primeira década do século $\mathrm{XX}$, momento em que o cinema deixou de ser apenas uma sequência de imagens em movimento e adotou o modelo narrativo-ficcional clássico.

As narrativas possuíam como personagens principais homens. Para as mulheres eram destinados papéis secundários e/ou atuavam como parte do cenário. Ao longo desses anos pudemos observar filmes que privilegiavam este grupo. Um dos gêneros mais conhecidos é o Western, que envolvem disputas, duelos e guerras. As histórias, em sua maioria, eram conduzidas através das trajetórias dos heróis do sexo masculino.
Dessa maneira, o cinema seguia os modelos criados pela sociedade patriarcal, na qual o homem tem domínio sobre a mulher e seus atos, comandava a vida dentro e fora de casa, excluindo as mulheres de papéis principais no espaço público. As personagens femininas eram, então, encontradas em melodramas familiares voltados ao espaço doméstico, e estas eram sempre salvas pelos homens pelo qual acabavam ficando junto no final.

De acordo com o livro A Mulher e o Cinema, de Ann Kaplan, a mulher, enquanto personagem, na maioria desses filmes, era tratada principalmente como objeto de desejo do olhar masculino. As personagens, então, eram construídas para serem observadas, e suas ações podiam ficar em segundo plano. Assim, às mulheres dos filmes clássicos não eram permitidos seus próprios desejos, satisfações pessoais, profissionais, etc. Raramente essa mulher era incentivada a ter coragem de perseguir seus próprios objetivos, o que fazia com que os filmes, na maioria das vezes, acabassem sendo construídos em torno do desejo masculino de possui-las. Outro aspeto desses filmes é que a história quase nunca era contada do ponto de vista feminino: a narrativa quase sempre se passava por intermédio do olhar masculino e de normas impostas pela sociedade que subjugava o papel da mulher, considerada como objeto para 
outro, conforme podemos confirmar na citação de Kaplan: "A mãe é transformada em ícone, presença perfeita e integralmente abnegada a serviço e dominada pelo pai. Ela é objeto-para-outro, antes que sujeito-para-simesma" (Kapplan, Ann. A Mulher e o Cinema, 1993).

$\mathrm{O}$ eu objeto e o eu sujeito confundem-se nessa concepção de vislumbrar o indivíduo. Assim, a visão patriarcal permitia que a mulher tivesse apenas um desejo que fosse bem visto pela sociedade: o desejo de ser mãe, todavia, essa vontade estava relacionada a ter um filho do pai, um herdeiro. Então, o desejo da mulher em relação a si própria acaba se anulando em detrimento de um ideal de família, concebido socialmente.

Simone de Beauvoir define de maneira singular a situação da mulher “(...) sendo como todo ser humano, uma liberdade autônoma, descobre-se e escolhe-se um mundo em que os homens lhe impõe a condição do outro" (Beauvoir:2009:30)

\section{Desenvolvimento}

\subsection{Almodóvar e o Melodrama}

Augusto Guzzo Revista Acadêmica, 2014, N 13
Pedro Almodóvar conseguiu romper com o estereótipo estabelecido pela sociedade em relação à mulher. Nos filmes do diretor, observamos que as personagens femininas são de extrema importância, ocupam papéis relevantes na sociedade, e ao mesmo tempo conseguem lidar com a maternidade como um desejo e realização próprios.

Essa peculiaridade na criação das personagens é beneficiada pela trajetória e experiência de vida do cineasta, que mescla elementos reais em suas tramas.

Pedro Almodóvar é um dos cineastas espanhóis mais conhecidos de todos os tempos. Nasceu em 24 de setembro de 1951 em uma pequena cidade espanhola. Em sua biografia, no livro Almodóvar e a feminilidade, ele relata a passagem de sua infância sempre cercado das mulheres de sua família. A partir de 1969, familiarizou-se com Madri: o ambiente, as ruas e a modernidade. Observamos que as histórias de seus filmes situam-se nesse espaço.

Ele não pôde estudar cinema, porque não tinha condições financeiras. Iniciou, na prática, escrevendo roteiros cômicos em revistas consideradas "undergrounds". 
Almodóvar só conseguiu comprar sua primeira câmera super 8, após obter um emprego fixo na Companhia Telefônica Nacional da Espanha. Ao filmar seus primeiros curtas-metragens, podemos observar alguns elementos que estarão presentes no decorrer de seu trabalho, como o uso da arte: cinema, televisão, voyeurismo. Esse voyeurismo é apresentado aos avessos por Almodóvar, pois o olhar recai sobre o homem e é lançado por uma mulher, rompendo com as estruturas tradicionais:

A imagem feminina é vinculada no cinema narrativo clássico à ameaça castradora, favorecendo a emergência de comportamentos perversos como o voyeurismo, fetichismo e o sadismo. É essa imagem congelada e antidiegética que impede o espectador de distanciar-se objetivamente.. No filme de Almodóvar porém esse olhar voyeurista recai sobre o homem e é lançado por uma mulher, que desmantela, assim, toda a rígida estrutura do cinema tradicional. (MELO 1996:251 apud in PEÑUELA)

Seu primeiro curta-metragem foi realizado em 1974, com o nome Dos Putas, o historia de amor que termina en borda (Dos Putas, o historia de amor que termina en borda). Em 1980 gravou seu primeiro longa-metragem:
Pepy, Luci, Bom y otras chicas de montom (Pepy, Luci, Bom y otras chicas de montom) e demorou cerca de um ano para ser finalizado por falta de verba. Em seguida fez Labirinto de Pasiones (Labirinto de Paixões), Maus Hábitos, ¿Qué he hecho yo para merecer esto!! (Que Fiz Eu Pra Merecer Isso?); Matador (Matador); La Ley Del Deseo (A Lei do Desejo); Mujeres al Borde de um Ataque de Nervios (Mulheres à Beira de um Ataque de Nervos).

Em 1990, Almodovar termina o projeto Tacones Lejanos (De Salto Alto), cujo roteiro havia começado durante a gravação de Atame (Ata-me).

De Salto Alto é filmado no ano de 1991, estrelado por Victoria Abril e Marisa Paredes e obteve bastante êxito na Espanha, na França e na Itália. O filme relata a história de uma mãe que abandona sua filha pequena para seguir a carreira de cantora internacional e volta anos depois, quando sua filha já está crescida e casada com seu ex-namorado.

Após isso dirigiu Kika (Kika), La Flor de me Secreto (A Flor do Meu Segredo), Carne Trémula (Carne Trêmula), Todo Sobre Mi Madre (Tudo Sobre Minha Mãe), estrelado por Cecília Roth e Penélope Cruz em 1999; o filme conta a história de Manuela (Cecília 
Roth) que é mãe-solteira e após a morte de seu filho decide procurar o pai do rapaz.

Em 2003, com Hable con Ella (Fale com Ela), ganhou o Oscar de melhor filme estrangeiro; em seguida dirigiu La Má Educação (Má Educação), Volver (Volver) em 2006 que narra a história de três gerações de uma família. Neste filme Penélope Cruz interpreta Raimunda uma mulher que tem problemas mal resolvidos com a sua mãe no passado e que, tenta se livrar do corpo do marido, assassinado pela sua filha para se livrar do abuso sexual, e em 2009, Los Abrazos Rotos (Abraços Partidos).

Nos filmes de Almodóvar, observamos um gênero muito recorrente: o melodrama.

É importante relembrar que há uma diferença estabelecida entre os melodramas em geral e os produzidos pelo diretor: sua preocupação central é privilegiar as mulheres, explorar amplamente suas emoções.Nas palavras de Laura Mulvey comprovamos que os melodramas exploram as emoções femininas, porém não são feitos para privilegiar as mulheres.

Esse gênero escolhido por Almodóvar apesar de remontar ao século XVIII, ainda faz muito sucesso com os espectadores em geral por tratar-se de situações que causam identificação e permeiam o cotidiano.

Sintetizando as palavras de Luiz Paulo Vasconcelos, em O Dicionário do Teatro, o melodrama é uma mistura de música incidental e ação dramática, sendo uma de suas características específicas intensificar virtudes e vícios das personagens, sejam elas vilãs ou heróis, enfatizando-lhes artificialmente algumas características, pois o objetivo maior desta estética é impressionar e comover cada espectador, através da verossimilhança.

Uma novidade entre as características das mulheres do cinema clássico, típico de Hollywood e as presentes na filmografia do cineasta é que essas representantes têm seus próprios desejos e objetivos, e são capazes de se reconstruir a cada instante. Esse fato faz com que Almodóvar, no decorrer de sua cinematografia, consiga transmitir uma visão própria sobre o universo feminino.

Esse universo não pode ser analisado somente pelo aspecto imagético, é necessário perceber a presença dos fatores sociais e culturais que interferem nessa construção da imagem, assim, ao mostrar um lado hegemônico da mulher, sua independência e o poder de "dar a volta por cima” precisam ser verificados os 
papéis e funções que as mulheres assumem dentro da sociedade. Andréa Mota Bezerra de Melo relata a respeito da opinião de Almodóvar:

$\mathrm{Na}$ opinião do cineasta, a sociedade, sobretudo, a espanhola, vive constantemente à iminência de um ataque, pois não aceita que a moral estabeleça apenas uma ordem "virtual" e que, portanto, está sujeita ao desgoverno pela intervenção do desejo. (apud. MELO, 1996:239 In PEÑUELA)

Nos filmes. essas personagens não são oprimidas pelos tabus e repressões. A forma como Almodóvar lida com o feminino instiga diversos pesquisadores a buscar uma compreensão maior acerca dessa iconografia. Melo afirma que "a autonomia dos personagens de Almodóvar resulta da obediência cega aos desejos mais recônditos (MELO, 1996:235 in PEÑUELA). É como se essas personagens evocassem vozes saídas da boca da "1Sibila1, vozes com duplo sentido, ou seja, com interpretação duvidosa.

O diretor explora o corpo, no entanto não o faz de forma vulgar, valorizando o lado sensual da mulher. Também aborda com naturalidade assuntos e comportamentos tidos pela sociedade como marginais (a homossexualidade, o uso de drogas etc.).

1 Sibila é, essencialmente, o nome de uma sacerdotisa encarregada de dar a conhecer os oráculos de Apolo. Existe um grande número de lendas respeitantes $\grave{a}$ ou $a ̀ s$ Sibilas.

\subsection{A Maternidade}

As mulheres de Almodóvar foram tema para diversos estudos, porém esta pesquisa tem o intuito de abordar um lado do feminino que ainda não foi muito analisado: a maternidade. Para isto, serão estudados os filmes: De Salto Alto (1991), Tudo Sobre Minha Mãe (2001) e Volver (2006).

Em todos estes filmes é possível perceber que a maternidade se torna algo primordial para a trama e é discutida o tempo todo durante a história. As motivações e atitudes das personagens estão muitas das vezes ligadas ao amor maternal. As mães durante a história são capazes de qualquer ação por seus filhos, exceto em De Salto Alto, mas veremos no decorrer desta história uma reviravolta na qual a mãe tenta redimir a sua ausência.

Em De Salto Alto, Rebecca (Victoria Abril) é abandonada ainda criança pela sua mãe Becky (Marisa Paredes), que vai para o México seguir a carreira de cantora. Anos depois, Bekcy volta para a Espanha e as duas têm a chance de se reconciliar. Rebecca, porém, havia casado com um ex-marido de sua mãe, e isso vira um problema, até que ele seja assassinado. Rebecca e sua mãe, então, passam a ser investigadas pela polícia. Rebecca assume a culpa do assassinato em público e é presa, mas acaba envolvendo-se com o juiz. Após algum 
tempo, Rebecca ao descobrir que sua mãe está muito doente, resolve esclarecer a situação e confessa a autoria pela morte do ex-marido. Sua mãe, para salvá-la, assume o crime em seu lugar.

Mais uma vez é possível confirmar a força materna presente em seu discurso; a mãe prefere sacrificar-se em nome de um futuro feliz para a filha. Um amor de abnegação.

A mesma ênfase no sacrifício está presente em Tudo Sobre Minha Mãe, Manuela Cecília Roth) é uma mãe-solteira, dedicada. Ao ver seu filho Estebán (Eloy Azorín) falecer devido a um atropelamento no dia do próprio aniversário, decide voltar para Madri e procurar o pai do menino e contar-lhe toda a verdade. Durante a viagem, Manuela conhece Rosa1 (Penélope Cruz), que está grávida, e descobre que o pai da criança é o mesmo que o de seu filho. Contudo, ela também fica sabendo que Rosa é portadora do vírus HIV, por essa razão não consegue resistir ao parto e acaba falecendo. Manuela assume o papel de mãe do bebê. Após um período, reencontra

1 Com a perda de seu filho, Manuela sente-se desamparada e projeta em Rosa todo sentimento maternal, cuidando dela como se fosse sua filha. Com a morte de Rosa durante, o parto assume o papel de mãe do bebê.

Augusto Guzzo Revista Acadêmica, 2014, N N 13
Lola - o pai de seu filho, que agora é um travesti e consegue revelar toda a verdade.

As projeções de vínculo que Manuela estabelece com os vários personagens durante a narrativa são devido ao sentimento de perda desencadeado pela morte do filho, o qual gera uma necessidade de acolher e proteger aqueles que ela percebe como frágeis. Assim, a presença da característica recorrente e exacerbada da mãe dedicada.

As mesmas características do modelo mãe zelosa estão presentes em Volver, Raimunda (Penélope Cruz) descobre que sua filha, Paula (Yohana Cobo), matou seu marido que tentou abusar dela. Após isso sua mãe volta e revela que não está morta como todos pensavam. Raimunda e sua mãe tinham muitos malentendidos do passado. Com esse retorno, elas conseguem se reconciliar. Neste filme podemos ver três gerações de mulheres.

Uma das semelhanças encontradas em De Salto Alto e Volver é que a mãe desaparece nos dois filmes, porém por motivos diferentes: no primeiro, a mãe abandona a filha para seguir carreira de cantora no México e volta quinze anos depois, quando a filha já está crescida e casada. No segundo, a mãe passa anos como se estivesse morta e reaparece para se reconciliar com a filha. 
Mas a principal semelhança dos filmes é o "retorno" que propicia um significado novo à narrativa. Primeiramente em De Salto Alto, a volta da mãe de Rebecca irá gerar a reconciliação entre ambas. Em Tudo Sobre Minha Mãe, Manuela decide voltar para Madri, a cidade de onde havia fugido grávida, e lá acaba ficando com o filho de sua amiga Rosa, que morre durante o parto. Em Volver, a mãe de Raimunda retorna quando todos pensam que ela está morta para se reconciliar com a filha.

Esses fatos evidenciam que "a volta / o retorno" acrescentam algo positivo, uma reconciliação: a possibilidade de um novo começo. Almodóvar mostra que histórias que foram mal resolvidas no passado podem ter uma solução no futuro, e isso ocorre graças à volta das personagens ao seu lugar de origem, de onde, de certa forma, haviam fugido para esquecer ou amenizar os seus problemas. A "volta" por estar associada ao recomeço promove um final feliz para as personagens.

A relação entre passado e volta é citada em uma cena específica do filme Volver; Raimunda ainda acredita que sua mãe esteja morta e em uma festa, canta uma música diretamente relacionada à história do filme e ao medo de sua mãe de voltar e enfrentar os problemas do passado. Com o objetivo de elucidar a idéia de voltar, abaixo trecho traduzido da música Volver cantada pela personagem Raimunda:

“'Tenho medo do encontro

com o passado que volta

a enfrentar-se com minha vida...

Tenho medo das noites

que povoadas de recordações

encadeiam meu sonhar.

Mas o viajante que foge

cedo ou tarde detém seu andar.

E ainda que o esquecimento, que destrói tudo tenha matado minha velha ilusão guardo escondida uma esperança humilde que é toda a fortuna do meu coração.

Voltar!"2

A etimologia do termo volver3 já indica a ideia de erguer, dar a volta, fazer correr o tempo, meditar, refletir e essa é a proposta do cineasta em suas narrativas, fornecer oportunidades de reflexão e de retorno.

\subsection{Conflitos}

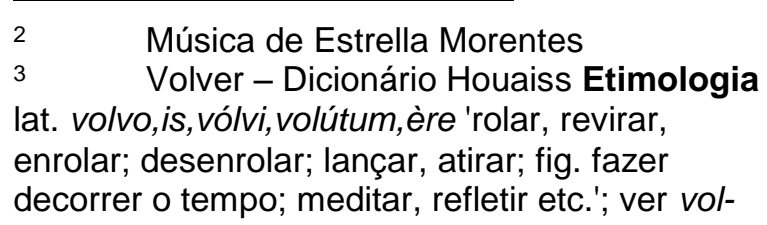


Nos três filmes analisados e também em várias outras obras de Pedro Almodóvar percebemos os homens sempre como causadores / geradores de conflitos. Em De Salto Alto, Rebecca, já tem conflitos com o seu padrasto desde o início, parte disso ocorre pelo sentimento de ciúme em relação à sua mãe. Para resolver este problema quando pequena acaba dando-lhe remédios para dormir antes de dirigir o que provoca um acidente e consequentemente sua morte; após vários anos, Rebecca casa-se com o ex-namorado de sua mãe, e, novamente por vários problemas e instabilidade no seu casamento ela assassina seu marido.

Os mesmos conflitos de relacionamento acontecem em Tudo Sobre Minha Mãe, Manuela foi casada com um homem que mais tarde se tornou travesti - Lola, os dois tinham vários problemas no casamento, como por exemplo, o ciúme excessivo de Lola. Manuela engravidou e decidiu fugir da cidade para que ele jamais descobrisse. Anos depois, com a morte de seu filho ao conhecer Rosa, as duas tornam-se amigas, entretanto, Manuela descobre que o mesmo homem que foi casado com ela há anos atrás se envolveu também com Rosa, que ficou grávida e contraiu HIV, mais uma vez ele não sabia da gravidez, que só foi lhe contada depois da morte de Rosa.
Lola não é o único exemplo de homem como elemento complicador no filme, observamos também o pai de Rosa, um senhor com problemas de memória e sempre faz as mesmas perguntas "Quanto você mede?", "Quanto você pesa?", como se os homens não conseguissem desenvolver um diálogo com as mulheres que fugissem à monotonia. Sua esposa durante o filme repete várias vezes "que vive para cuidar dele", ou até "que o homem dá mais trabalho do que uma criança". Nesse caso observa-se que a relação marido $\mathrm{x}$ mulher praticamente não existe mais e que a mulher precisa tomar uma postura maternal em relação ao marido que necessita de cuidados. Ela está sempre preocupada em saber onde ele está indo, se saberá voltar para casa, etc. O pai sequer lembra de sua filha Rosa, e quando a reencontra em uma praça conversa com ela como se fosse uma desconhecida, ou seja, por causa da falta de memória a relação entre pai $\mathrm{x}$ filha acaba sendo dificultada.

Já em Volver, Raimunda, quando adolescente sofreu abuso pelo próprio pai em sua casa, e mais tarde relembra a cena, ao saber que seu marido tentara abusar da filha. 
Essa figura do homem causador / gerador de problemas fica também evidente em diálogos nos quais as mulheres sempre reclamam deles e se mostram, na maioria das vezes, infelizes com suas vidas amorosas. É também notável que nenhuma das mulheres tem um relacionamento estável, porque até mesmo as personagens que são casadas tem uma vida alvoroçada ao lado de seus companheiros, inclusive em Volver, a personagem Irene, mãe de Raimunda, que acreditara ter um casamento feliz descobre que o marido além de tentar abusar de sua filha, tinha uma amante. As mulheres dizem que são "bobas" por dependerem ou sofrerem por algum amor mal resolvido.

Mas, além de todas estas evidências contra os homens, também fica claro nesses filmes que a ligação mãe x filho(a) é muito mais forte do que pai $\mathrm{x}$ filho, esta última quando acrescentada à trama acontece de um modo sempre conturbado.

Afinal, os pais não costumam ser lembrados pelas personagens e quando citados trazem más lembranças, principalmente para as mães. Em Tudo Sobre Minha Mãe, Estebán sequer conhecia seu pai, apesar de ter este sonho, sua mãe jamais contou algo sobre ele, nem lhe deu a oportunidade de conhecê-lo. De uma maneira generalizada, os homens não contribuem na educação dos filhos, e quando estão em casa são vistos apenas como um empecilho, conforme podemos constatar em em Volver. Pacco acaba de perder o emprego e passa suas tardes vendo televisão, ele não se mostra preocupado em nenhum momento. Em Tudo Sobre Minha Mãe, Lola também nunca procurou Manuela para saber o que lhe aconteceu, ou seja, o homem também é visto nos filmes de Almodóvar como "conformado", os personagens não demonstram interesse e, por essa razão a história jamais poderia acontecer em torno deles.

A mãe, nesses filmes, assume a postura de chefe de família, a visão patriarcal da sociedade é rompida, as mulheres comandam suas casas, suas vidas e têm a hegemonia da sociedade, elas assumem as funções principais e se tornam responsáveis pelas suas próprias vidas.

Uma diferença evidente é que, em De Salto Alto, a mãe abandona sua filha, não é uma mãe como as personagens Manuela e Raimunda, que se mostram dedicadas e que tem diálogos como "sou capaz de fazer qualquer coisa por você" - e, realmente, essas mães são capazes de qualquer ato por amor aos seus filhos. 
Nesses trabalhos, observamos também mães coadjuvantes. Em De Salto Alto, a mãe do juiz Eduardo, embora apareça poucas vezes se mostra uma mulher neurótica e bastante exagerada, está sempre preocupada e é de certa forma estereotipada. Em Tudo Sobre Minha Mãe, Rosa, amiga de Manuela, tem um relacionamento perturbado com a mãe, que rejeita o fato de sua filha ser freira e dedicar sua vida aos outros. Com isso, Rosa e sua mãe têm uma relação instável e com muitas brigas. A mãe não aceita a decisão da filha, isso acontece porque a mãe projeta na filha a sua própria figura.

Simone de Beauvoir elucida a ideia acima:

" $\mathrm{Na}$ filha (...) procura o seu duplo. Projeta nela toda a relação de ambigüidade de sua relação consigo mesma; e quando se afirma a alteridade desse alter-ego, sente-se traída.

Há mulheres que se acham suficientemente satisfeitas com a vida para desejar reencarnarse na filha, ou pelo menos acolhe-la sem decepção; desejarão dar a filha a oportunidade que tiveram e também as que não tiveram(...)" (Beauvoir, 2009:688)

A mãe de Rosa se mostra preconceituosa durante a trama, não quer que seu marido saiba da gravidez de Rosa e pede para que
Manuela guarde segredo. De certa forma, a mãe de Rosa se envergonha do fato da filha ter contraído HIV, e tê-lo transmitido ao neto.

Percebe-se também que profissões relacionadas à comunicação são muito recorrentes nestes filmes. Em De Salto Alto, Rebecca é uma apresentadora de telejornal, e sua mãe é uma cantora com grande sucesso. Em Tudo Sobre Minha Mãe, o filho de Manuela morre depois de assistir uma peça de teatro, que sua mãe também havia interpretado há vários anos quando era atriz. Algumas personagens do filme também são atrizes.

Em Volver, apesar de nenhuma personagem trabalhar com profissões relacionadas à comunicação, a música está presente e emociona quando Raimunda em seu restaurante ao tocar uma música diz que aprendeu com sua mãe para ir a um programa de televisão cantar quando pequena.

\subsection{Estética e linguagem}

A estética criada para revelar as mães, tornamnas ainda mais femininas. Almodóvar compõe isto através das cores, falas, expressões e atitudes das personagens. As mães estão de 
certa forma, sempre em busca da aprovação dos filhos. Apesar dos problemas da vida, as mães de Almodóvar nunca se consideram vítimas das situações nas quais até poderiam ser, dependendo de como a narrativa fosse conduzida pelo diretor. Isso é evidenciado em Volver, a trama poderia ter sido explorada por outro ângulo, tornando-o essencialmente um drama, contudo Pedro Almodóvar conduz a trajetória da personagem de forma diferente.

As mães sempre se colocam como únicas responsáveis pelos filhos, assumindo até os erros deles, por exemplo, quando Paula mata Pacco à facadas, para se livrar do abuso, Raimunda para proteger a filha diz que assumirá a culpa do assassinato do marido, caso alguém descubra, e depois consegue se livrar do corpo dele, mantendo-o dentro de um refrigerador.

Observamos em De Salto Alto, que a mãe de Rebecca também assume a culpa no lugar da filha. Ao responsabilizar-se, ela tenta de certa forma obter o perdão da filha por todos os anos de abandono. Essas mulheres querem evitar, o máximo possível, o sofrimento e o julgamento de suas filhas perante a sociedade, portanto, preferem serem condenadas.

Uma coincidência relevante é a escolha de títulos para três filmes pesquisados: eles interagem também com o mundo feminino. Primeiro, De Salto Alto, o sapato de salto alto é exclusivo do universo feminino; em Tudo Sobre Minha Mãe, o título traz a palavra mãe, aqui o tema principal é a maternidade e por fim Volver, em que o próprio título indica "voltar", e como já analisado anteriormente, todos os filmes têm uma volta e todas elas acrescentam algo novo para a história dos filmes, ou seja, os títulos estão interligados e de certa forma, antecipam a história do filme e a pesquisa feita pode também ser resumida a estas três etapas: mulher, mãe e volta. 


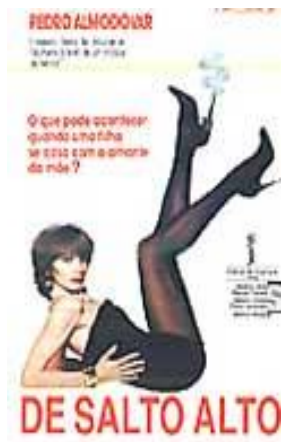

Em relação aos filmes clássicos, podemos constatar uma mudança com relação ao final, pois Almodóvar está preocupado, conforme dissemos, com a Volta, com o Retorno, com a Reflexão. O final da história é um "personagem" a mais que pede ao espectador que faça a sua parte, concluindo-o. Isso significa que muitas vezes, o final da história fica em aberto, para o espectador ter o seu próprio julgamento e / ou público não pense

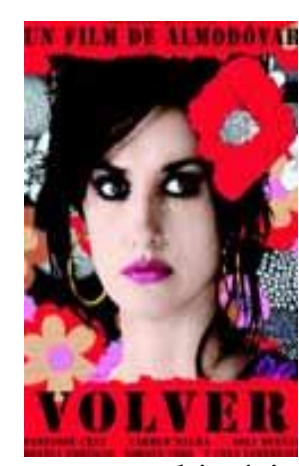

que a história daqueles personagens simplesmente acabou porque o filme teve um fim, que a história e a relação delas terá uma continuidade na imaginação do espectador.

Almodóvar costuma trabalhar com as mesmas atrizes em filmes diferentes. Em nosso corpus de análise, temos como exemplo Penélope Cruz atuando como Rosa em Tudo Sobre Minha Mãe, como Raimunda em Volver:

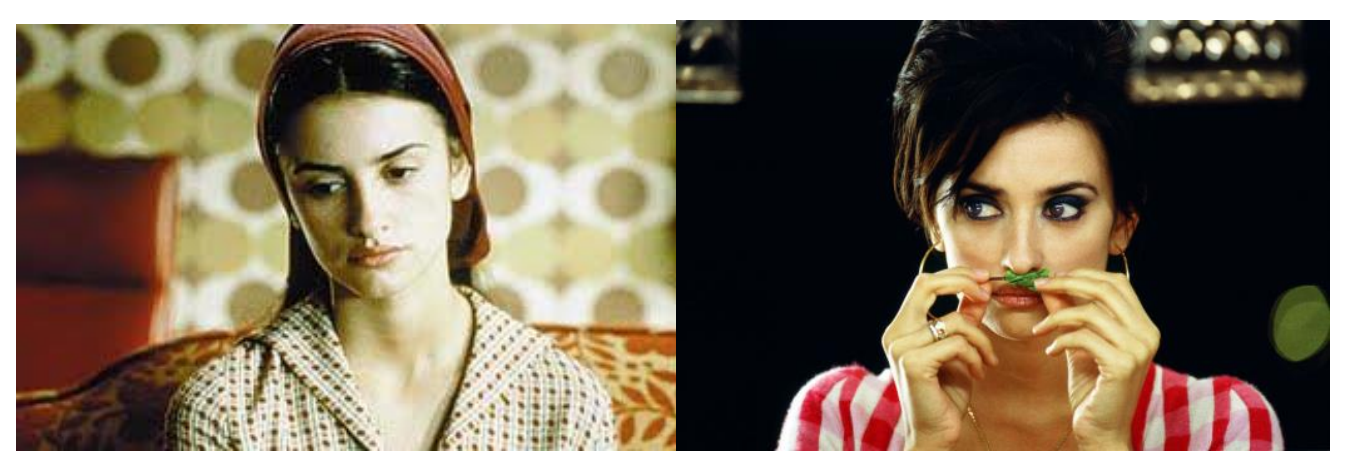

Penélope Cruz em Tudo Sobre Minha Mãe

Penélope Cruz em Volver

Marisa Paredes em De Salto Alto e Tudo Sobre Minha Mãe, no primeiro interpreta
Rebecca e no segundo, Huma Rojo uma atriz de teatro: 


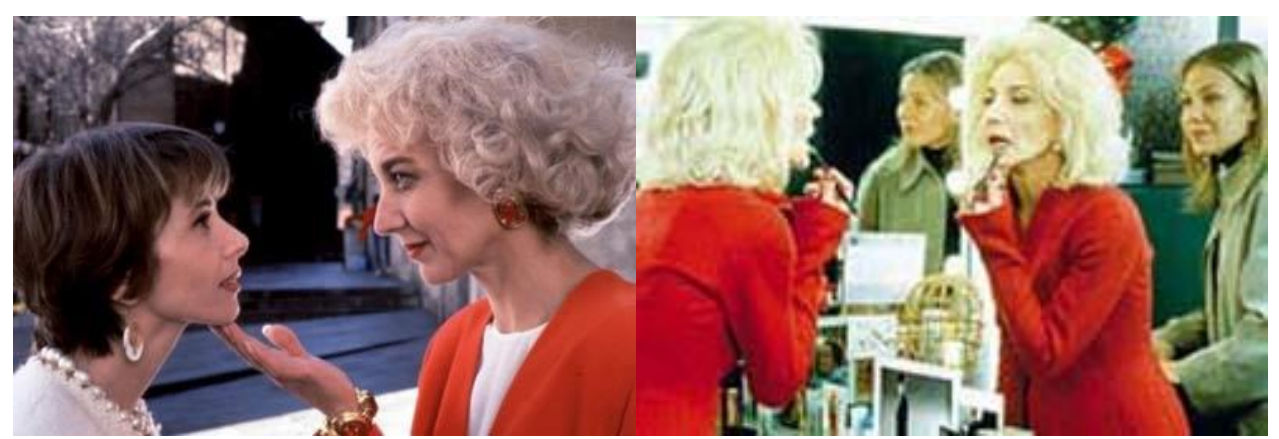

Marisa Paredes em De Salto Alto

Marisa Paredes em Tudo Sobre Minha Mãe

Quanto ao figurino e cenário, percebemos a recorrência de cores quentes, principalmente o vermelho. Esta escolha é observada na maioria dos filmes de Pedro Almodóvar, o que ajuda na construção do perfil dos personagens, a escolha das cores ressalta ainda mais o quão vivas e importantes a mulheres são nas suas tramas. Nas três imagens, percebemos a opção pelos tons vermelhos em seus figurinos.

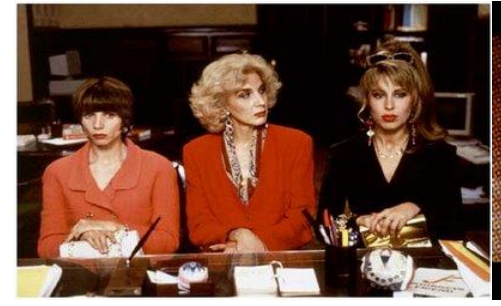

De Salto Alto

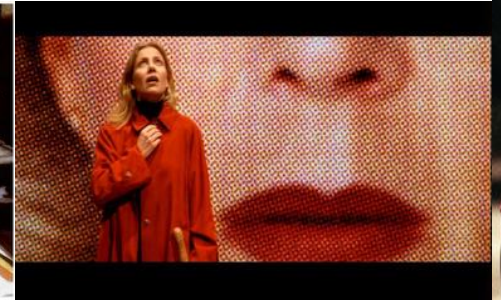

Tudo Sobre Minha Mãe

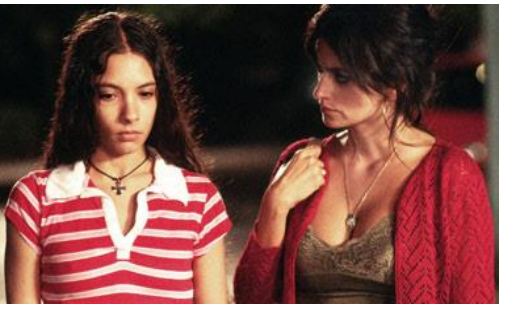

Volver
Abaixo vemos as seguintes imagens: De Salto Alto, Tudo Sobre Minha Mãe e por último
Volver. Podemos perceber a semalhança dos planos nos três filmes.

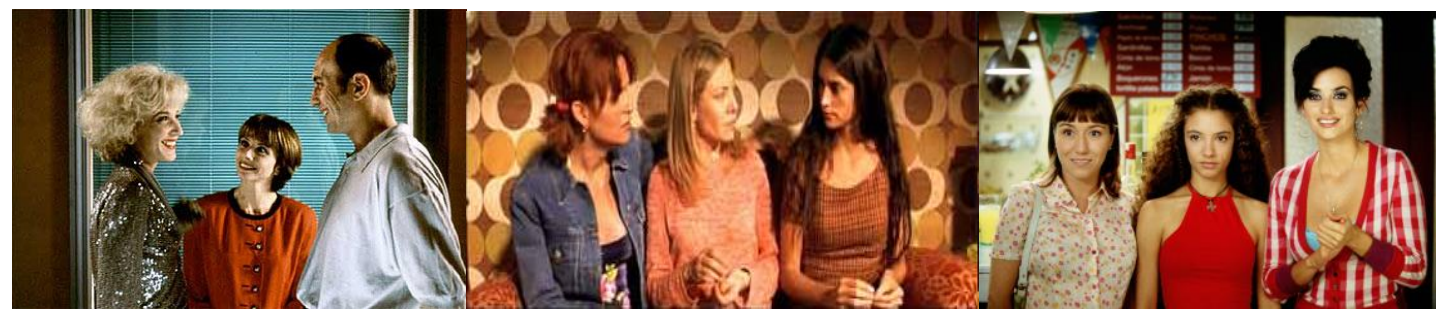

De Salto Alto

Tudo Sobre Minha Mãe

Volver 
É importante reiterar que Almodóvar não cria as mulheres de suas tramas a partir do olhar masculino. Em seus filmes, a mulher não é vista como um objeto e não aparece somente para satisfazer o voyeurismo masculino. O diretor não as torna objeto de desejo e não as oprime, não condicionando assim as suas personagens à sociedade exclusivamente de dominância masculina. Essas mulheres estão sempre enfrentando problemas de forma bastante corajosa, não parecem com mocinhas típicas dos filmes mais tradicionais de Hollywood, que na maioria das vezes, inclui o herói do sexo masculino como integrante de um final feliz. As 'mulheres e mães' de Pedro Almodóvar possuem autonomia para alcançar a felicidade.

\section{Considerações finais}

É impossível citar as obras de Pedro Almodóvar sem mencionar suas personagens femininas. $\mathrm{O}$ diretor é conhecido em todo o mundo como um cineasta de mulheres. A feminilidade nos filmes de Almodóvar também é um personagem e muitas vezes, o personagem principal da trama.

O que diferencia Pedro Almodóvar da maioria dos cineastas é que em toda a trama dos seus filmes, desde a narrativa até a decupagem, todos os elementos corroboram para favorecer exclusivamente as mulheres, que ocupam sempre papéis de extrema importância. As personagens estão repletas de desejos e de objetivos e não estabelecem uma relação de dependência com as figuras masculinas para alcançá-los, ou seja, as mulheres desprendem-se totalmente da imagem masculina que, nos filmes, são abordados como geradores/causadores de adversidades para as mulheres; a presença de um homem na trama só torna a vida das personagens mais conturbadas.

Em relação à construção dos vínculos, observamos uma não-afetividade pai x filho / filho $\mathrm{x}$ pai, os quais se direcionam em uma ordem inversa da que é pré-estabelecida socialmente/culturalmente, dissociando-se inclusive dos aspectos biológicos que deveriam promover a afetividade entre ambos. O pai é apenas um objeto genitor que contribui com a concepção do indivíduo, exercendo uma função subjacente.

Portanto nas palavras de Simone de Beauvoir: "Se a mulher se enxerga como inessencial que nunca retorna ao essencial é porque não opera ela própria, esse retorno.” (Beauvoir, Simone de 2009:19)

... E Almodóvar é o cineasta de alma feminina que ajuda neste processo de VOLVER. 


\section{Referências bibliográficas}

ALMODÓVAR, Pedro. Tudo sobre mi madre. Guión original de Pedro Almodóvar. Madrid: El Deseo Ediciones, 2001

BEAUVOIR, Simone de. O Segundo Sexo. Rio de Janeiro:Nova Fronteira, 2009 CAÑIZAL, Eduardo Peñuela. Urdidura de Sigilos: Ensaios sobre o cinema de Almodóvar. São Paulo: AnnaBlume, 1996

KAPLAN, Ann. A mulher e o cinema: Os dois lados da câmera. Rio de Janeiro: Rocco, 1993.

MELO, Andréa Mota Bezerra. A presença Feminina no Cinema de Almodóvar in CAÑIZAL, Eduardo Peñuela (org). Urdidura de sigilos - Ensaios sobre o cinema de Almodóvar. São Paulo:Annablume, 1996.

RODRIGUES, Ana Lucilia. Pedro Almodóvar e a feminilidade. São Paulo: Escuta, 2008.

VASCONCELOS, Luiz Paulo. A História do Teatro. Porto Alegre: P\&M, 2001

STRAUSS, Frederic. Conversaciones com Pedro Almodóvar. Akal: Verona, 2001

Sites Consultados:

www.allmodovar.com.br www.imdb.com www.webcine.com.br/historia.htm http://houaiss.uol.com.br/ 